Thorax (1958), 13, 1.

\title{
THE CONGENITAL SHORT OESOPHAGUS
}

BY

\author{
P. M. PETERS \\ From the Central Histological Laboratory, Archway Wing, Whittington Hospital, London, and the \\ Department of Pathology, the Royal Northern Hospital, London
}

(RECEIVED FOR PUBLICATION OCTOBER 4, 1957)

There are two closely related developmental abnormalities which are rare predisposing causes of the common digestion oesophagitis. These are (a) congenital shortness of the squamous oesophagus, and (b) congenital enlargement of the oesophageal hiatus of the diaphragm. This paper presents an account of the pathology of 25 cases.

It is now generally agreed that many cases of short oesophagus with hiatal hernia were previously described as congenital on insufficient evidence ; by far the commonest cause is acquired chronic cicatrizing reflux or digestion oesophagitis. There is, however, a risk that the pendulum may swing too far the other way and the existence of the congenital lesion be generally denied or forgotten.

Findlay and Brown Kelly (1931) collected seven post-mortem congenital cases from the literature, the earliest by Richard Bright in 1836. In two of the cases (Bund's and Huffman's) other congenital anomalies were present. Hume (1932) described a case and stressed the accompanying enlargement of the hiatus.

In 1950 Barrett published three cases which are included in the present series; he suggested that certain chronic oesophageal ulcers reported previously by Tileston (1906), Stewart and Hartfall (1929), and Lyall (1937) were "gastric" ulcers in congenital partial thoracic stomachs. $\mathrm{He}$ also raised the at first sight startling question, "What is an oesophagus?" Barrett claimed that any part of the alimentary tract above the diaphragm lined with gastric mucosa continuous with the stomach proper must be regarded as partial thoracic stomach whatever the gross morphology. If not covered by peritoneum, it was an extension of the bare area normally seen above the peritoneal reflections at the cardiac end. Allison (1951) contested this view; if in gullet form, the anomaly was best described as oesophagus with atypical (gastric) lining, as gross morphology could not be ignored. There is the point here, however, that the normal gastric cardia, although very short, is essentially a tube.

Both these interpretations were developed in later papers (Allison and Johnstone, 1953 ; Barrett, 1954). In addition, Allison and Johnstone recorded islands of squamous epithelium in the gastric-lined segment (see also Morson and Belcher, 1952), and oesophageal glands in the submucosa. I made similar observations independently (Peters, 1952). In the differential diagnosis, Allison and Johnstone suggested that healing of oesophagitis in a continuing acid medium might be by gastric type epithelium rather than by squamous epithelium. There is clear histological evidence, however, that squamous regeneration from residual islets occurs readily even in the distal oesophagus (Peters, 1955).

Barrett (1957) has recently modified his view. $\mathrm{He}$ regards the lower atypical segment as representing an embryonic maturation failure and suggests the lesion be called " the lower oesophagus lined by columnar epithelium."

The congenital short oesophagus is necessarily associated with a large hiatus unless the gastriclined part is wholly tubular, but the congenitally large hiatus can occur alone and appears to have been first reported by Harrington in 1940, who also described the embryological basis (vide infra).

\section{EMBRYOLOGY}

The first indication of the developing stomach is very early in intra-uterine life. In the fourth week (2-3 mm: embryo) a fusiform dilatation of the entodermal foregut develops in the cervical region, and this, the primitive stomach, is separated from the future pharynx by a constriction in the tube, the oesophageal anlage. At this stage the foregut, slung on a dorsal mesentery, is separated from the pericardium by the nearly vertical septum transversum, into the caudal part of which the liver bud from the lower end of the foregut pushes cranially. During the sixth week (5-10 $\mathrm{mm}$. stage) the growth and development of 
the oesophagus are rapid. As the bulk of the heart, lungs, and liver increases and the neck differentiates, the entodermal oesophageal tube elongates and concentric condensation of mesoderm around it foreshadows the development of submucosa and muscularis, the outer longitudinal muscle layer being indicated after the inner circular and the muscularis mucosae later still (Hamilton, Boyd, and Mossman, 1952). The superficial cardiac glands of the oesophagus begin to develop at four months or earlier, but the deep glands not until much later (Arey, 1934). The entodermal epithelium of the oesophagus is composed of small columnar cells, ciliated at one stage, which are later replaced by cells of squamous type. Lewis (1912) pointed out that the characteristic shape of the different segments of the alimentary tract is determined by differential growth of the entoderm epithelium, the outer mesodermal layers being modelled round and conforming to the inner tube, which is itself eventually represented by the definitive mucosa.

During the stage of rapid caudal migration the stomach starts to differentiate from a simple fusiform swelling into a structure with defined curvatures and recognizable pars cardiaca and tubular pars pylorica (Lewis, 1912). At the same time the septum transversum descends rapidly and rotates so that it lies nearly horizontally, thus separating the ventral parts of the developing thoracic and abdominal cavities. The pleuroperitoneal ridges descend with the septum transversum, and both for a short time outstrip, so to speak, the elongation of the oesophagus, so that the stomach is temporarily cranial to the developing diaphragm. During the seventh week (11-18 $\mathrm{mm}$.) the continued elongation of the oesophagus is such that the stomach rapidly overtakes and passes the septum transversum and comes to lie in the future abdominal cavity, and during the eighth week the membranous diaphragm is completed round the lower end of the oesophagus. Muscularization of the diaphragm closely follows the growth in membrane. Differentiation in the developing oesophagus is seen in Figs. 1-3, to obtain which two well-preserved embryos of the approximate stated ages were embedded in wax, in the left lateral position, and cut through in serial sections $5 \mu$ thick. Fig. 4 shows a hernial sac formed by a greatly stretched membranous dome in a case where muscularization of the diaphragm had failed to take place.

If the elongation of the oesophagus is prematurely arrested, part or the whole of the stomach remains in the thorax and the diaphragm forms round it. If, as Harrington (1940) pointed out, the elongation of the oesophagus is merely delayed, even for a short time, the diaphragm again forms round the stomach and the resulting large hiatus persists, even though by subsequent growth of the

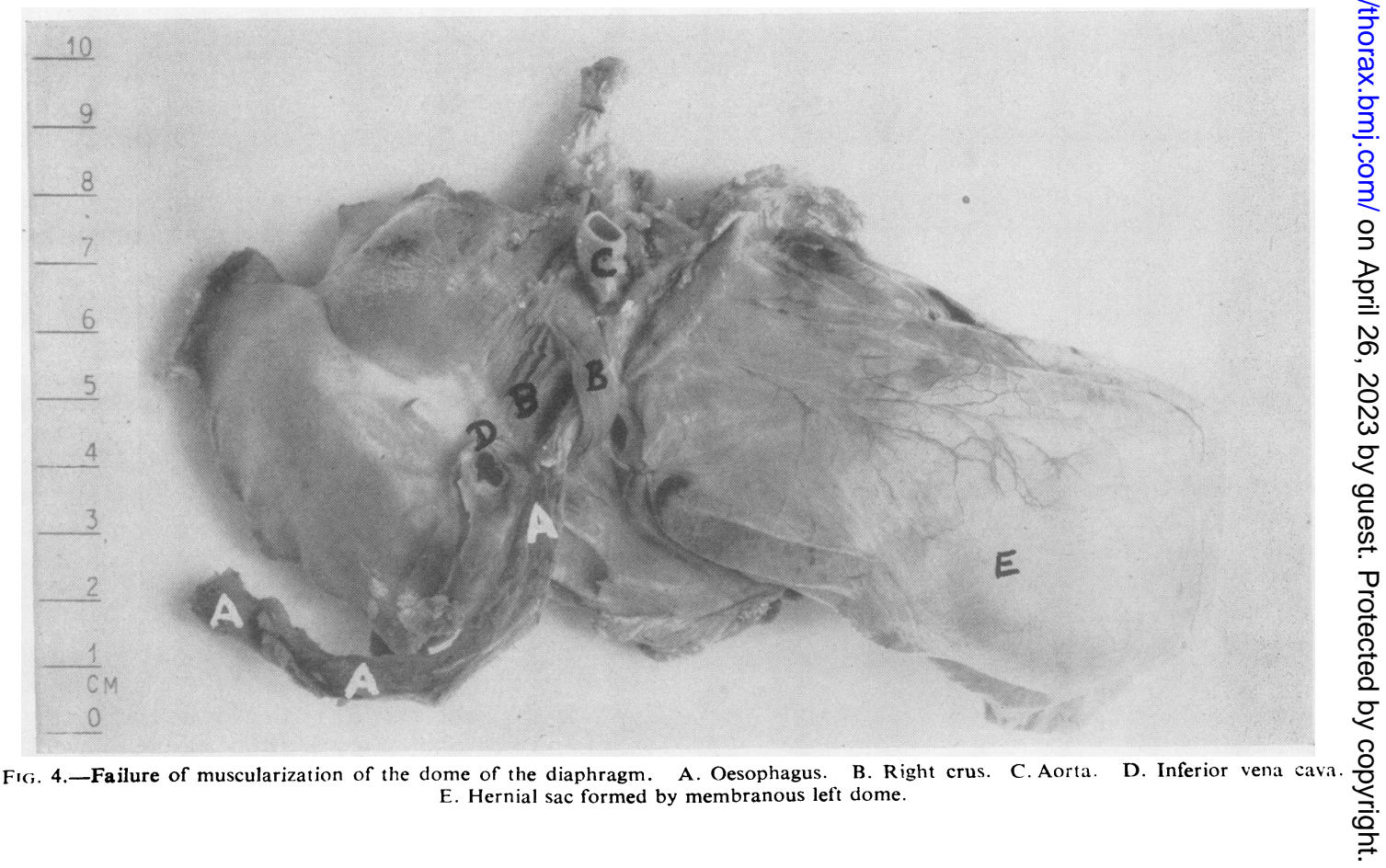




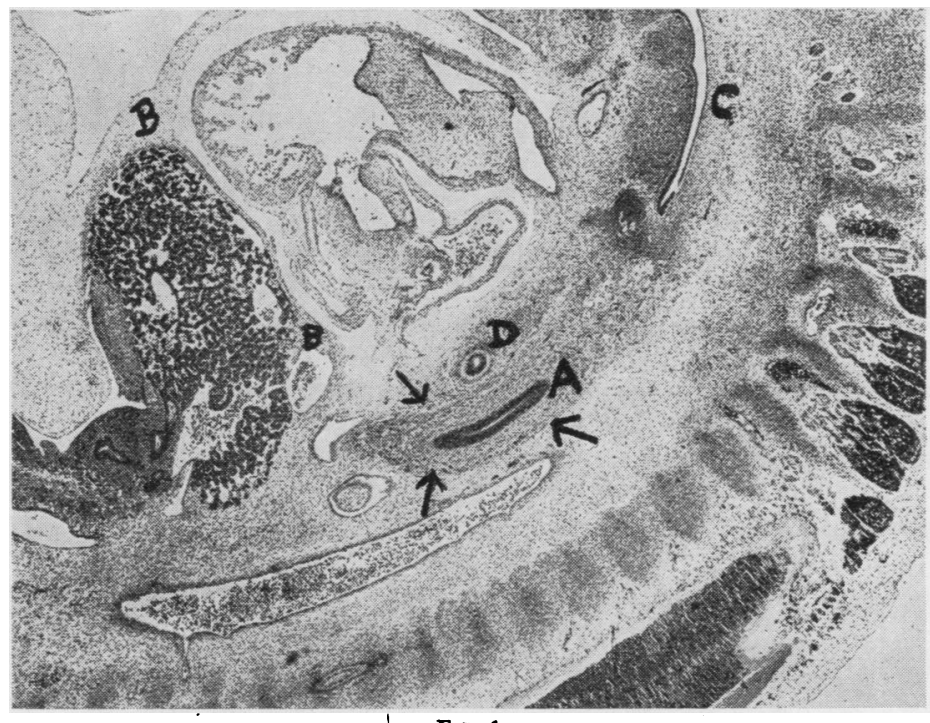

Fig. 1.-Primitive oesophagus showing early condensation of mesoderm (arrows) round entodermal foregut. Section taken from a 11-12 mm. human embryo (approximately 40 days' fertilization time). Haematoxylin and eosin. $\times 22$. A. Oesophagus. B.

Septum transversum. C. Pharynx. D. Respiratory tubule.

Fio 1

FIG. 2.-Detail of Fig. 1. Haematoxylin and eosin $\times 61$. A. Oesophagus B. Septum transversum.

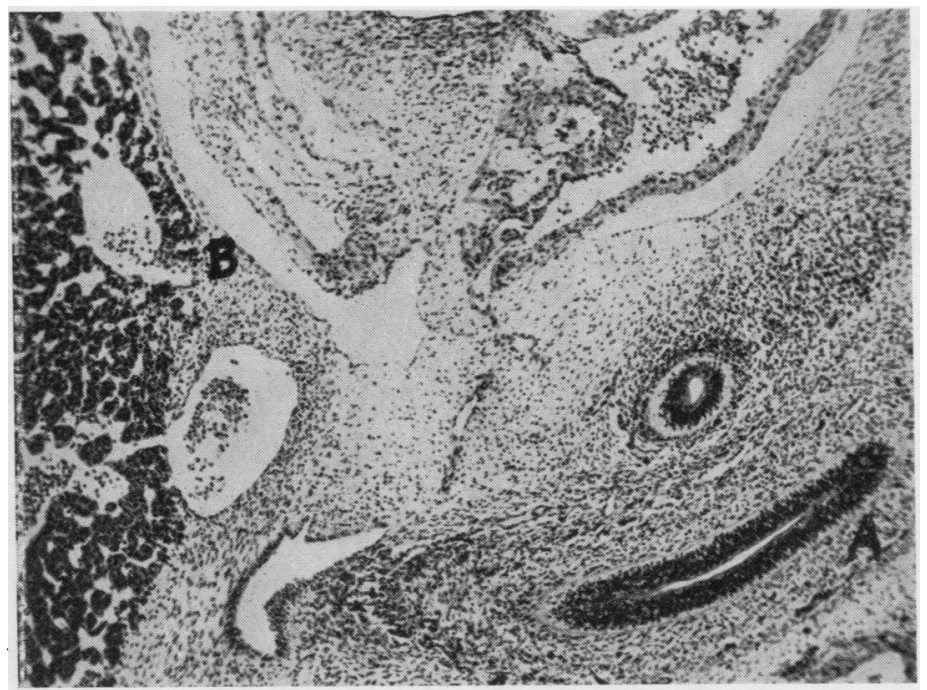

FIG. 2

Fig. 3.-Further differentiation of oesophagus. Muscularization of membranous diaphragm (arrow). Section taken from a $30 \mathrm{~mm}$. human embryo (approximately 56 days' fertilization time). Similar field and same magnification as Fig. 1, but about 16 days older. A. Oesophagus. B. Diaphragm. C. Liver. D. Adrenal. E. Heart.

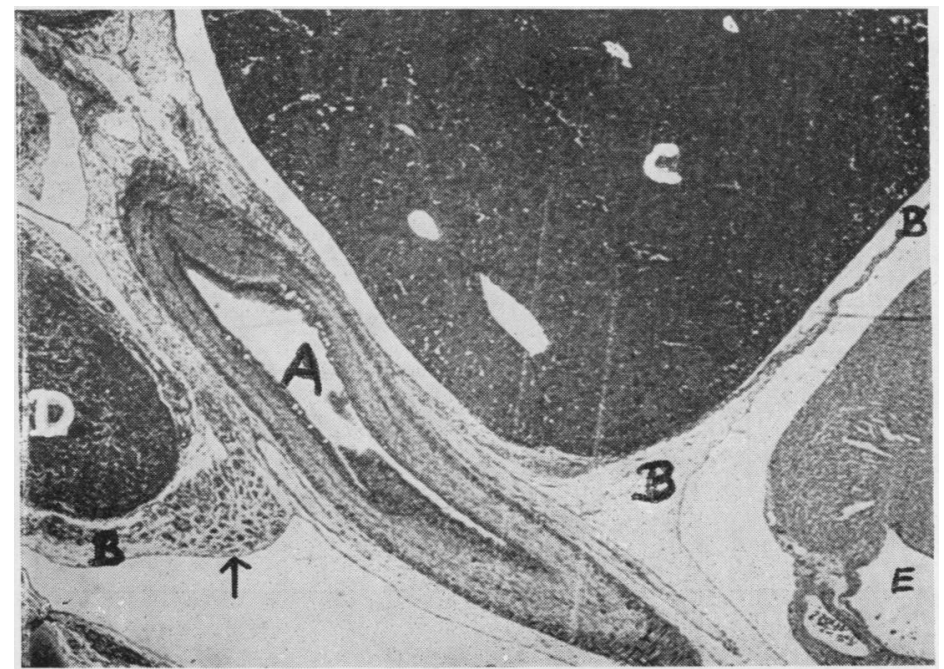

Fio. 3 
oesophagus the stomach later becomes a wholly abdominal organ. Slightly asynchronous development may thus be responsible for some cases of large hiatus with sliding gastric hernia in postnatal life.

It is thus seen that the most important stages in the highly complex evolution of the oesophagus, stomach, and diaphragm occur from the fourth to the eighth weeks of development, and the malformations to be discussed in this paper presumably originate thus early in embryonic life.

\section{Present Material}

The following investigations are based on 25 cases collected at necropsy ( 21 of congenital short oesophagus, four of congenital large hiatus alone). The main findings are shown in Tables I and II.

MoRBid ANATOMY.--In the congenital short oesophagus the external appearances depend on the form of the gastric-lined lower part and the type and degree of the digestion oesophagitis which is usually present in the short squamous part. If severe, the latter may show externally as an indurated stricture, sometimes as high as the bifurcation of the trachea, but in such heavily scarred cases the evidence for an underlying congenital abnormality needs to be very strong. The lower gastric portion varies in gross morphology ; it may be (a) tubular, (b) conical or inverted funnel-shaped, $(c)$ both successively, or $(d)$ resembling normal stomach. These forms are usually fairly clear cut, but sometimes intermediate nondescript specimens are seen. A characteristic of all the forms, naturally least in the tubular type, is a soft bulkiness when inspected and felt from the outside ; this may also be present in some cases of severe oesophagitis, because of inflammatory swelling, but only in very minor

TABLE I

CASE ANALYSIS

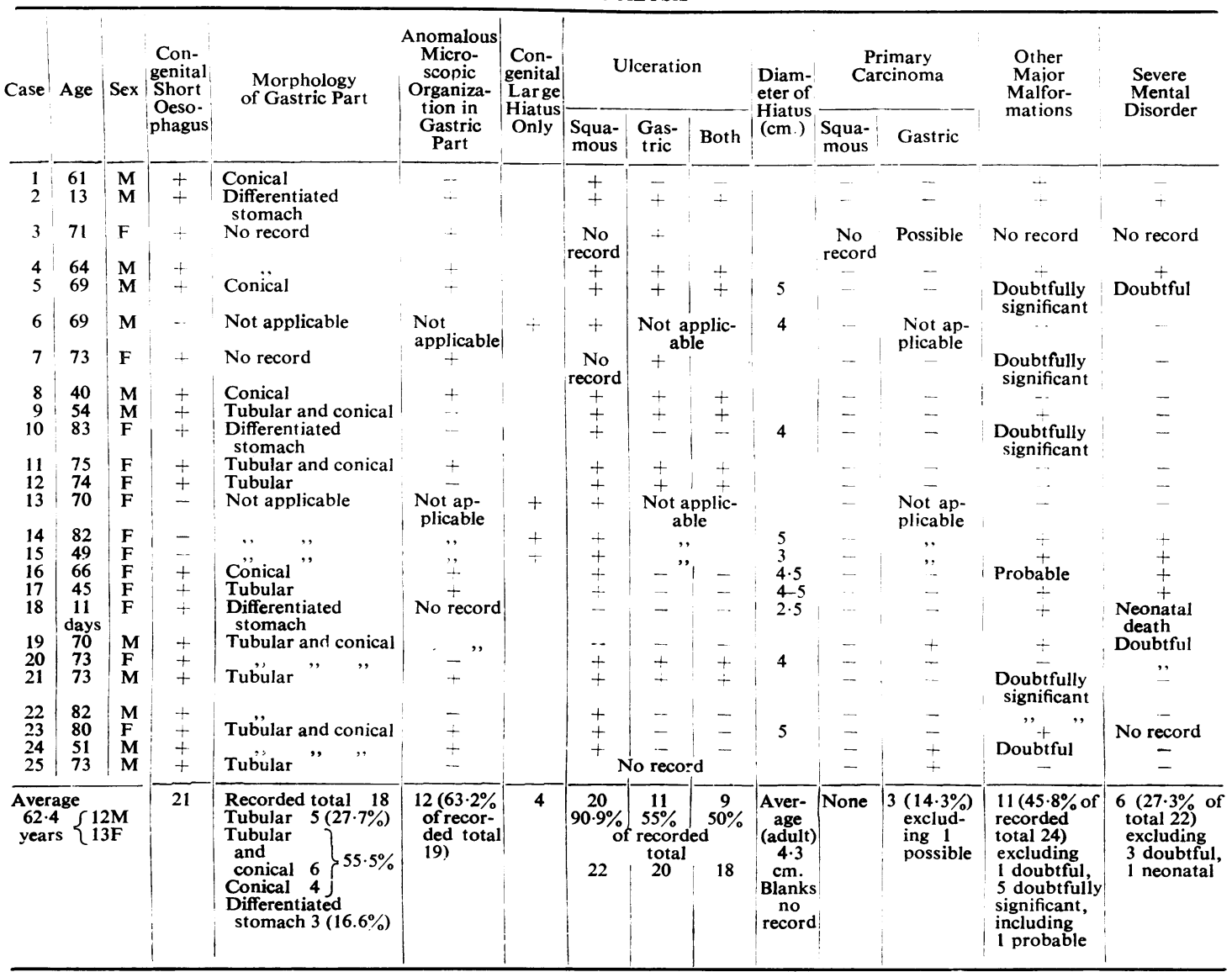


TABLE II

ASSOCIATED CONGENITAL MALFORMATIONS

\begin{tabular}{|c|c|c|c|c|c|c|c|}
\hline \multicolumn{2}{|l|}{ Kidney } & \multirow[b]{2}{*}{ 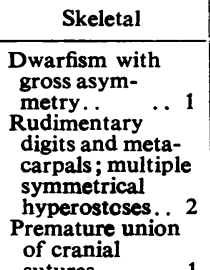 } & \multicolumn{2}{|c|}{ Cardiovascular } & Gastro-intestinal & Miscellaneous & Doubtful or Doubtfully Significant \\
\hline $\begin{array}{l}\text { Hypoplasia } \\
\text { Double pelvis } \\
\text { Polycystic }\end{array}$ & $\begin{array}{l}\ldots 4 \\
\ldots 1 \\
\ldots\end{array}$ & & $\begin{array}{l}\text { Fallot's } \\
\text { tetralogy }\end{array}$ & $\ldots 1$ & $\begin{array}{l}\text { Ectopic gastric } \\
\text { mucosa in } \\
\text { proximal oeso- } \\
\text { phagus .. } 1 \\
\text { Ectopic pancreas } \\
\text { in duodenum } 1\end{array}$ & $\begin{array}{l}\text { Mesenteric cyst } 1 \\
\text { Congenital } \\
\text { cataracts } \ldots 1 \\
\text { Angiomatous } \\
\text { hamartoma of } \\
\text { brain .. } \\
\text { Malformation of } \\
\text { liver (both lobes } \\
\text { equal in size } \\
\text { and shape) .. } 1\end{array}$ & 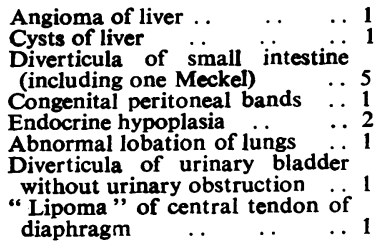 \\
\hline
\end{tabular}

degree. In the more differentiated types distinction from the far more common acquired fixed hiatal hernia with cicatrizing oesophagitis (see Table III) may be difficult, but in the latter condition the intrathoracic gastric cone is usually much smaller. The visceral attachment of the elastic hiatal ligament may be well below the level of the squamo-glandular junction, and is then good evidence of a congenital anomaly. Similarly the reflections of the peritoneum do not usually follow the thoracic course of the abnormal stomach.

Internally the combined viscus shows mucous membrane of two types. Proximally, for a length varying in the adult from 6 to $18 \mathrm{~cm}$., is the greywhite squamous epithelium, usually with general or focal leukoplakia and irregular superficial ulceration towards the lower limit. The amount of fibrosis is very variable. Below the squamous length is the atypical gastric-lined part, the junctional zone sometimes jumbled and not clear cut (Fig. 8). The quite distinct brownish velvety mucosa is continuous with that of the main part of the stomach. As would be expected, there is some correlation between gross morphology and type of mucosa. Tubular forms and the proximal tubular parts of more differentiated forms have a smooth lining, microscopically cardiac in type ; in the junctional zone proper, however, an artefact to be borne in mind is post-mortem desquamation with exposure of normal oesophageal cardiac glands (Peters, 1955). In the expanded more differentiated (conical) parts the mucosa is rugose and microscopically may contain oxyntic cells (sometimes abundantly) and occasionally the gastric feature of two crosswise layers in the muscularis mucosae (Fig. 15).

Ulcers in the gastric part are sometimes shallow, necrotic and haemorrhagic (Figs. 5 and 12) and sometimes of classical excavated and fibrous form (Figs. 9 and 14). Metaplasia to epithelium of intestinal type may occur round the ulcers (Morson, personal, communication).
The microscopic organization may be atypical in two particulars (vide supra). Oesophageal mucous glands with typical periductular lymphoid aggregates may be seen in the submucosa below frank gastric epithelium (Fig. 17), and islets of well-differentiated squamous epithelium may be seen embedded in or focally replacing the gastric epithelium (Fig. 16). Both these features, in my belief, are of positive significance in the diagnosis. The squamous islets may be just visible macro-

TABLE III

DIFFERENTIATION OF. CONGENITAL AND ACQUIRED SHORT OESOPHAGUS

\begin{tabular}{|c|c|}
\hline $\begin{array}{c}\text { Congenital Short Squamous } \\
\text { Oesophagus } \\
\text { (All Morphological Types) }\end{array}$ & $\begin{array}{c}\text { Acquired Short Oesophagus } \\
\text { with Fixed (Gastric) Hiatal } \\
\text { Hernia }\end{array}$ \\
\hline $\begin{array}{l}\text { 1. Gastric cone in chest usually } \\
\text { high and bulky (least in simple } \\
\text { tubular forms) }\end{array}$ & $\begin{array}{l}\text { Gastric cone in chest small (up } \\
\text { to } 3 \mathrm{~cm} \text {. on average) }\end{array}$ \\
\hline $\begin{array}{l}\text { 2. Associated digestion oesopha- } \\
\text { gitis in squamous part often } \\
\text { not of excessively fibrous type, } \\
\text { i.e., insufficient fibrosis to fix } \\
\text { an acquired gastric thoracic } \\
\text { pouch }\end{array}$ & $\begin{array}{l}\text { Sufficient fibrosis present for } \\
\text { fixation of hiatal hernia with } \\
\text { permanent shortening (usu- } \\
\text { ally with stricture) }\end{array}$ \\
\hline $\begin{array}{l}\text { 3. Gastric cone may not be } \\
\text { covered with peritoneum or } \\
\text { only in part }\end{array}$ & $\begin{array}{l}\text { Gastric cone has normal } \\
\text { peritoneal covering }\end{array}$ \\
\hline $\begin{array}{l}\text { 4. Diaphragmatico-oesophageal } \\
\text { elastic ligament may be at- } \\
\text { tached well below the squamo- } \\
\text { glandular junction }\end{array}$ & $\begin{array}{l}\text { Diaphragmatico-oesophageal } \\
\text { ligament attached roughly at } \\
\text { or above the squamo-glandu- } \\
\text { lar junction }\end{array}$ \\
\hline $\begin{array}{l}\text { 5. Hiatus often very large and } \\
\text { circular }\end{array}$ & $\begin{array}{l}\text { Hiatus usually only slightly } \\
\text { enlarged and elliptical shape } \\
\text { usually preserved }\end{array}$ \\
\hline $\begin{array}{l}\text { 6. Anomalous microscopic struc- } \\
\text { ture may be demonstrable }\end{array}$ & $\begin{array}{l}\text { No anomalies of microscopic } \\
\text { structure. Acquired morbid }\end{array}$ \\
\hline $\begin{array}{l}\text { (a) May be deep oesophageal } \\
\text { mucous glands in sub- } \\
\text { mucosa below gastric epi- } \\
\text { thelium }\end{array}$ & \\
\hline $\begin{array}{l}\text { (b) May be squamous islets em- } \\
\text { bedded in gastric epithel- } \\
\text { ium }\end{array}$ & \\
\hline $\begin{array}{l}\text { (c) Glandular epithelium } \\
\text { (above the insertion of the } \\
\text { elastic ligament) usually } \\
\text { cardiac in type, sometimes } \\
\text { fundal with oxyntic cells }\end{array}$ & \\
\hline $\begin{array}{l}\text { 7. Commonly associated with } \\
\text { major malformations else- } \\
\text { where }\end{array}$ & $\begin{array}{l}\text { No special association with } \\
\text { malformation }\end{array}$ \\
\hline
\end{tabular}




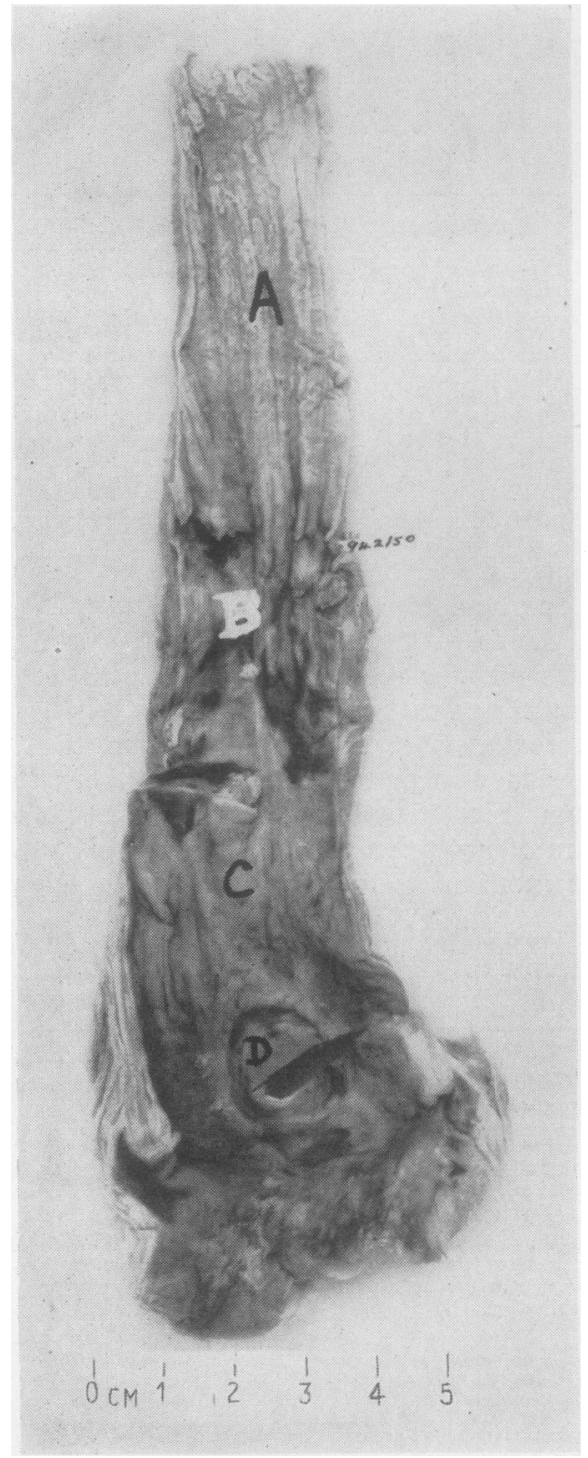

FIG. 5

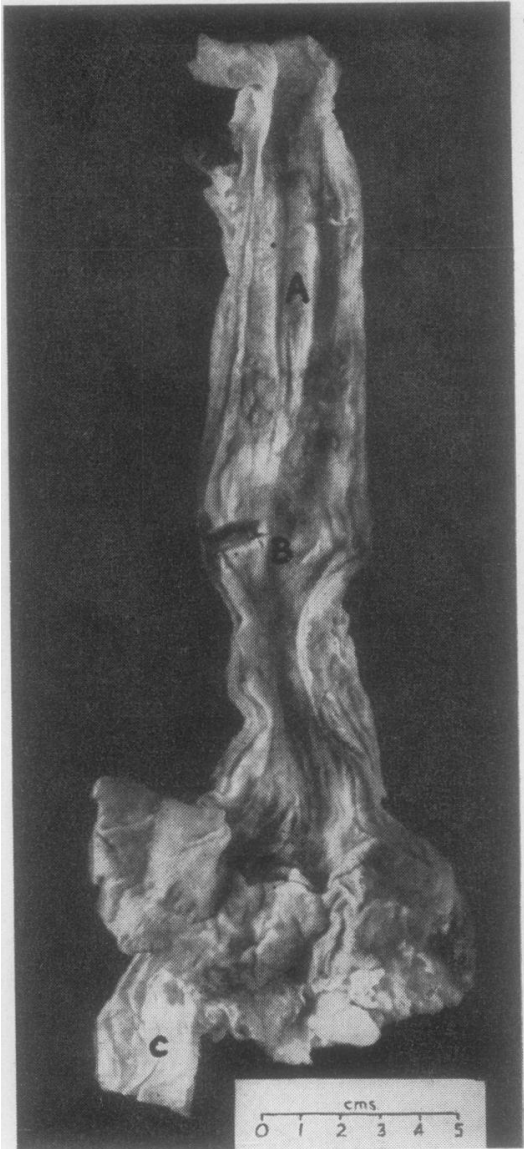

F10. 6

FIGS. 5-9.-Congenital short squamous oesophagus : gastric part in tubular form.

FIG. 5.-A. Squamous-lined proximal part. B. Chronic digestion ulceration of lower end of squamous part. C. Gastric-lined distal part. D. Shallow chronic "gastric" ulcer. Specimen reproduced by kind permission of Mr. Barrett and the editor and publishers of the British Journal of Surgery.

FIG. 6.-A. Squamous-lined part, ulcerated at lower end. B. Gastriclined part. C. Diaphragm.

FIg. 7.-A. Squamous-lined part with ulceration and leukoplak ia in the lower end. B. Gastric-lined part. C. Diaphragm.

FIG. 8. Snakeskin leukoplakia above jumbled epithelia at junctional zone (detail of Fig. 7). A. Squamous plaques. B. Gastric mucosa. C. Ulcerated areas.

FIG. 9.-A. Squamous-lined part, lower half ulcerated. B. Gastriclined part. C. Chronic "gastric" ulcer (Barrett's ulcer). D. Diaphragm.

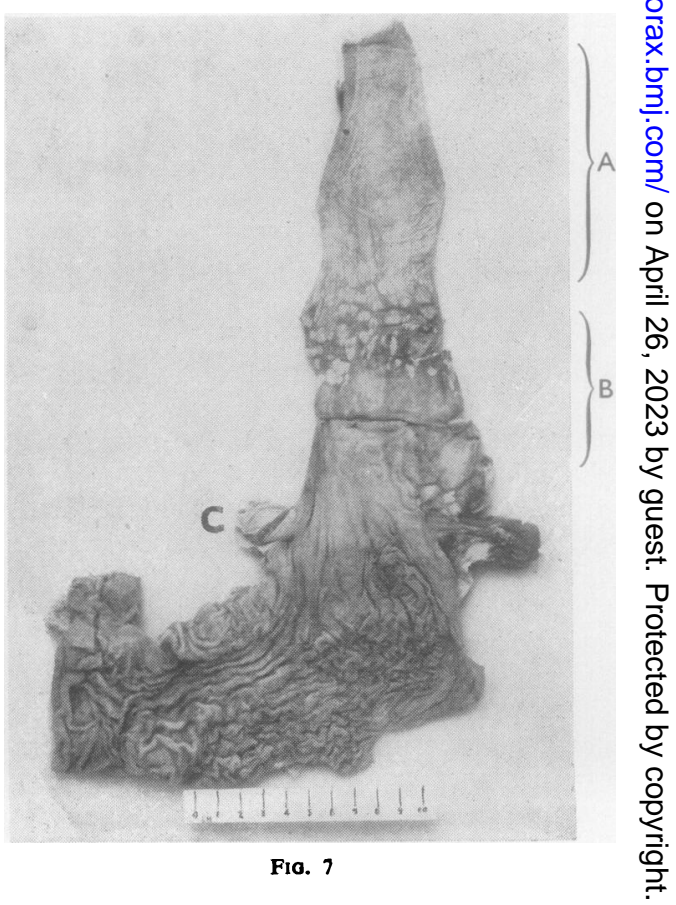




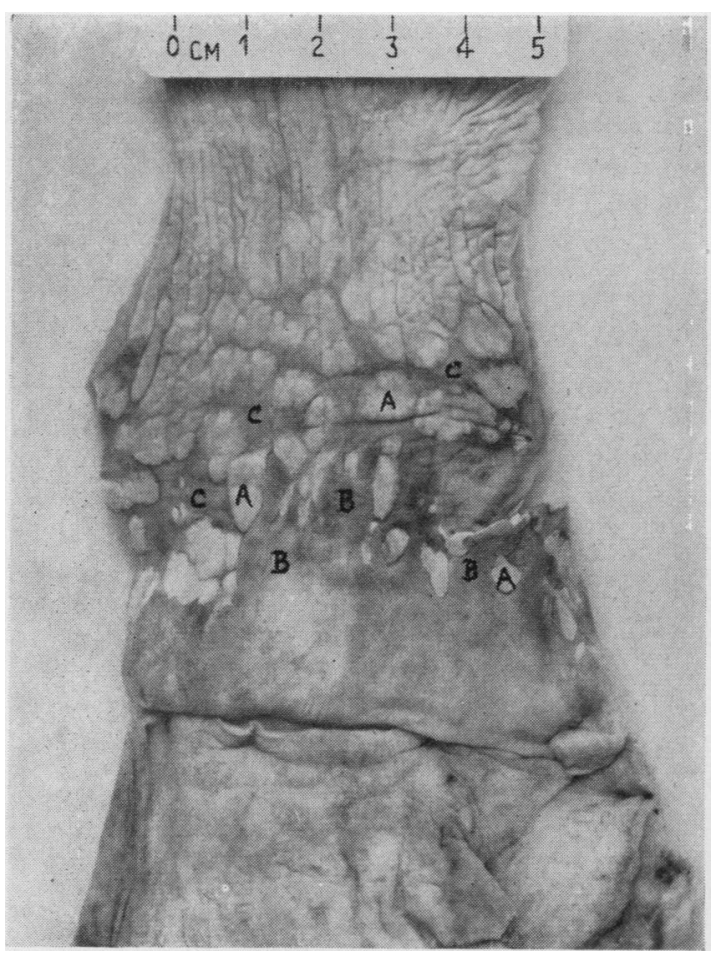

Fig. 8

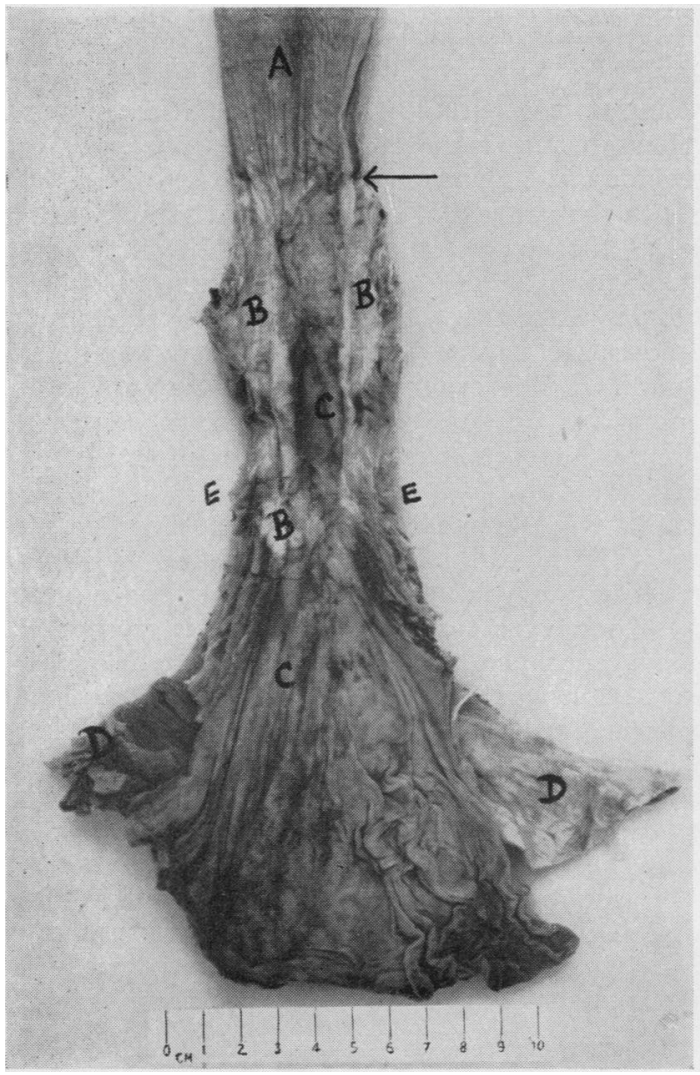

FIG. 10

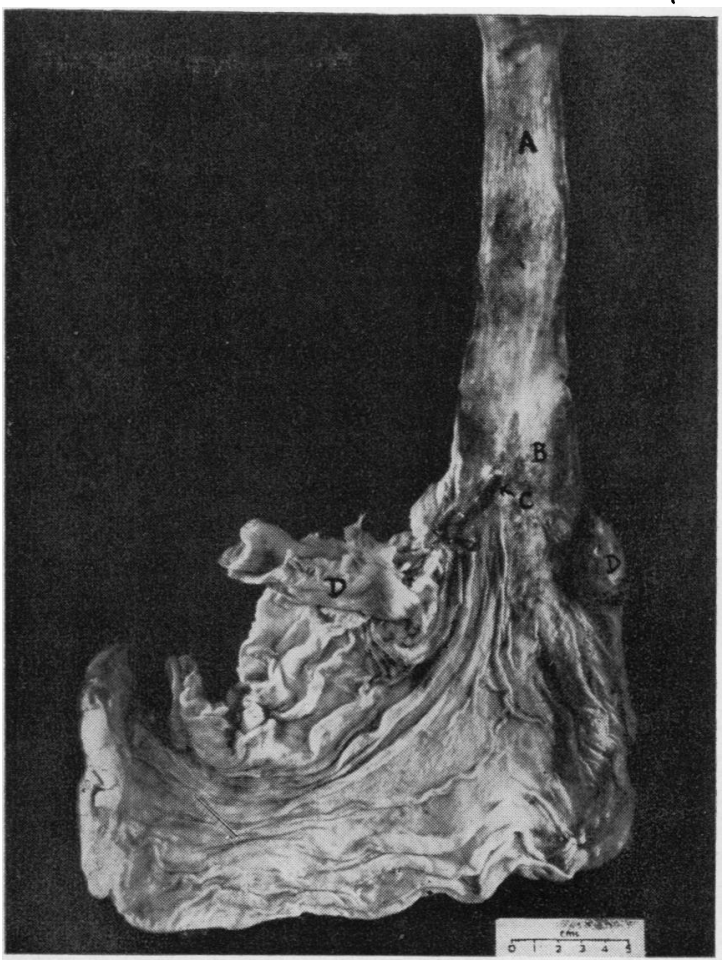

Fio. 9

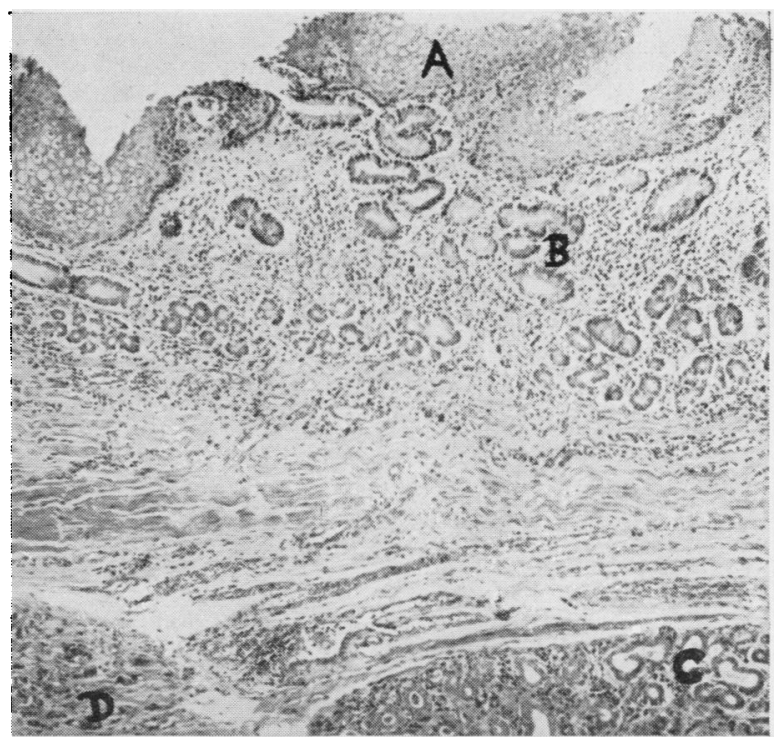

Fio. 11

FIG. 10.-Congenital short squamous oesophagus. Tubular and conical gastric part, with primary adenocarcinoma. A. Squamous part. B. Carcinoma. C. Non-ulcerated gastric mucosa, rugose in expanded part. D. Diaphragm. E. Approximate insertion of stretched elastic diaphragmatico-cesophageal ligament. Arrow, compare Fig. 11

FIG. 11. - Typical cardiac (junctional) arrangement, in this case high in the thorax. Haematoxylin and eosin $\times 54$. A. Squamous epithelium. B. Cardiac glands. C. Oesophageal submucosal gland. D. Carcinoma. (Compare arrow in Fig. 10.) 


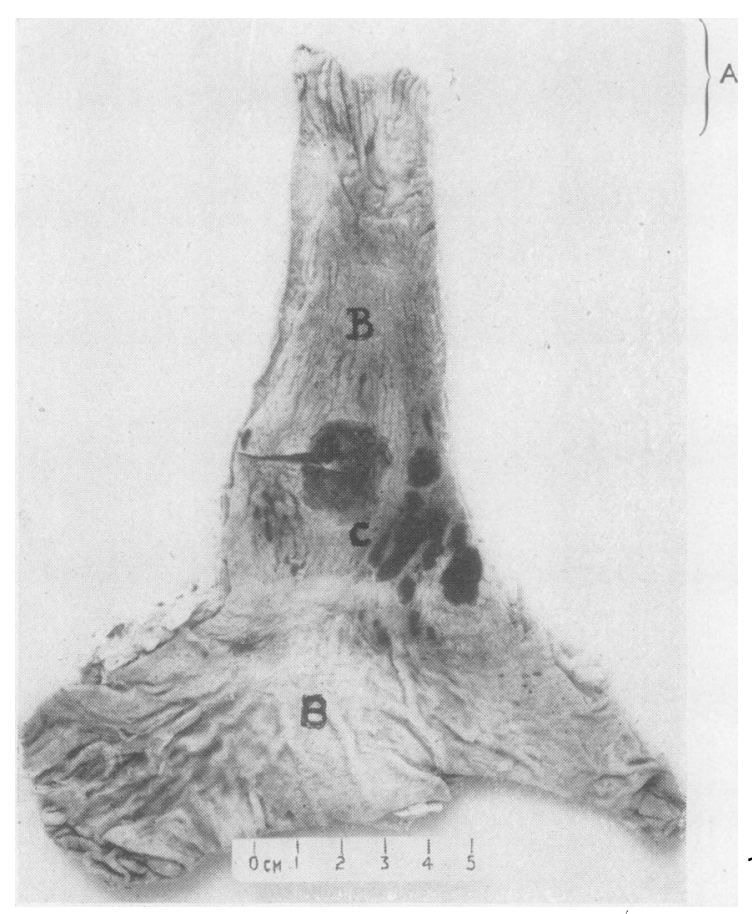

FIG. 12.-Congenital short squamous oesophagus, showing tubular and conical gastric part. (The whole specimen was supradiaphragmatic.) A. Lower end of squamous part. B. Gastric mucosa, rugose in expanded part. C. Haemorrhagic ulcers. Specimen reproduced by kind permission of Mr. Barrett and the iditor and publishers of the British Journal of Surgery.

scopically (Fig. 14) or occasionally be in larger plaques (Figs. 8 and 14), and they not infrequently occur in the margins of ulcers (Fig. 13). This raises the possibility that such ulcers may in some cases actually form through these squamous foci; in any fully established ulcer it is of course impossible to have certain knowledge of the type of epithelium which has disappeared; this can only be inferred. As the epithelium proper to the gullet is squamous, neither " metaplasia" nor "ectopic islet" appear appropriate terms for such foci, which are best regarded as areas of normally differentiated epithelium surrounded by aberrant mucosa.

The main muscular coats of the anomalous viscus consist of normal and well-defined inner circular and outer longitudinal layers and do not contribute to the differential diagnosis. In two cases of this series, both of simple tubular form, there appeared to be general hypoplasia of the whole wall. In the adventitia, the insertion of the elastic hiatal ligament far below the squamoglandular junction may be confirmed microscopically.

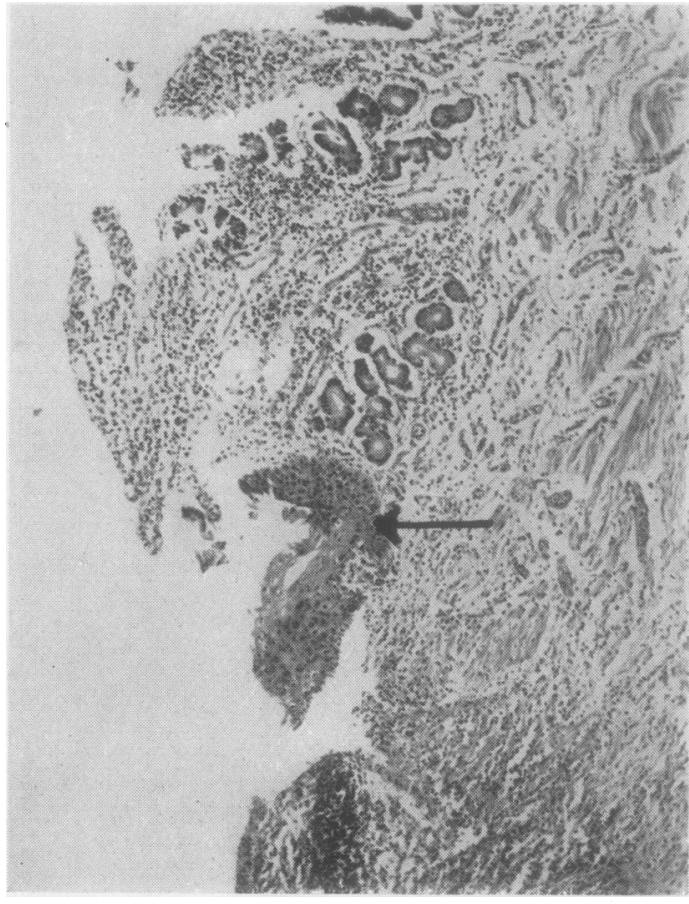

FIG. 13.-Margin of ulcer with squamous islet (arrow) included in gastric mucosa (detail of Fig. 12). (See also Figs. 15 and 16.) Haematoxylin and eosin. $\times 60$.

Points in the pathological differentiation of the congenital and acquired short oesophagus are listed for convenience in Table III.

As to the congenital large hiatus without shortness of the squamous oesophagus, this may be difficult to distinguish from the common atrophic or toxic lax hiatus; therefore the four present examples are advanced as probables rather than certainties. The criteria used were the size and shape of the opening, supported indirectly in two cases by the occurrence of major malformations elsewhere.

The average diameter of the hiatus (recorded in three of four cases) was $4 \mathrm{~cm}$., compared with the average of $4.5 \mathrm{~cm}$. in the six adult.congenital short oesophagus cases in which it was recorded. In one specimen $(5 \mathrm{~cm}$. diameter) the hiatal organization was dissected fully and the opening was found to lie as usual in the right crus. The large hiatus appeared circular and not elliptical and was spanned by a hypertrophied elastic ligament (Figs. 20 and 21). This circular shape was thought to be important as well as the size, because in the common acquired hiatal deficiencies the normal elliptical shape seems to be surprisingly long retained. In all four cases chronic digestion oesophagitis was present. 


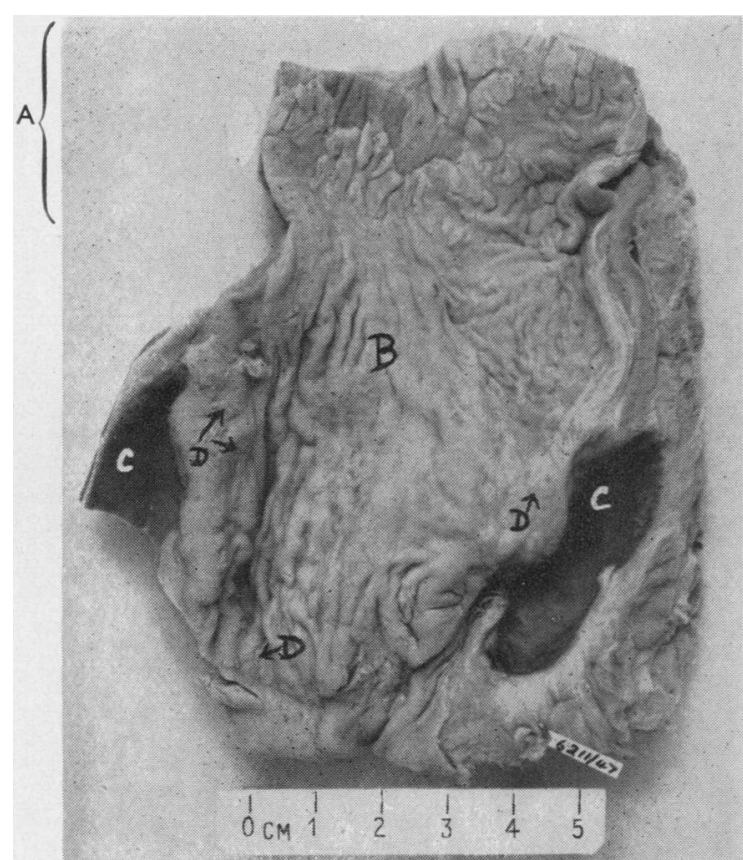

FIG. 14.-Distal part of congenital short squamous oesophaguis. A. Jumbled epithelia at junctional zone. B. Rugose gastric mucosa. C. Large chronic "gastric" ulcer (Barrett's ulcer). D. Minute squamous islets.

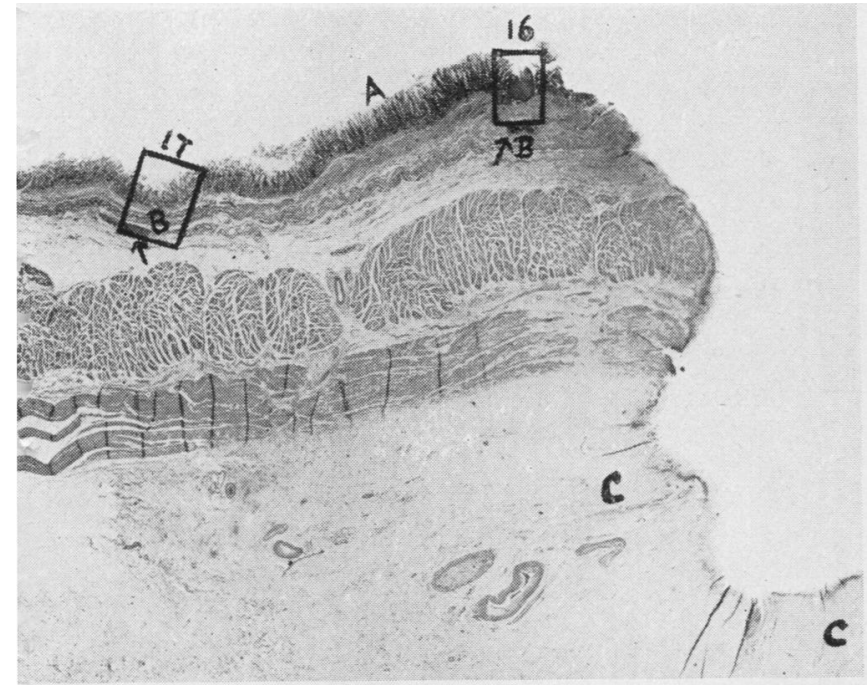

FIG. 15.-Margin of chronic " gastric" ulcer. Note two-layer muscularis mucosae. A. Gastric mucosa. B. Oesophageal glands in submucosa. C. Fibrous ulcer floor. (Inset see Figs. 16 and 17.) Haematoxylin and eosin $\times 4$.

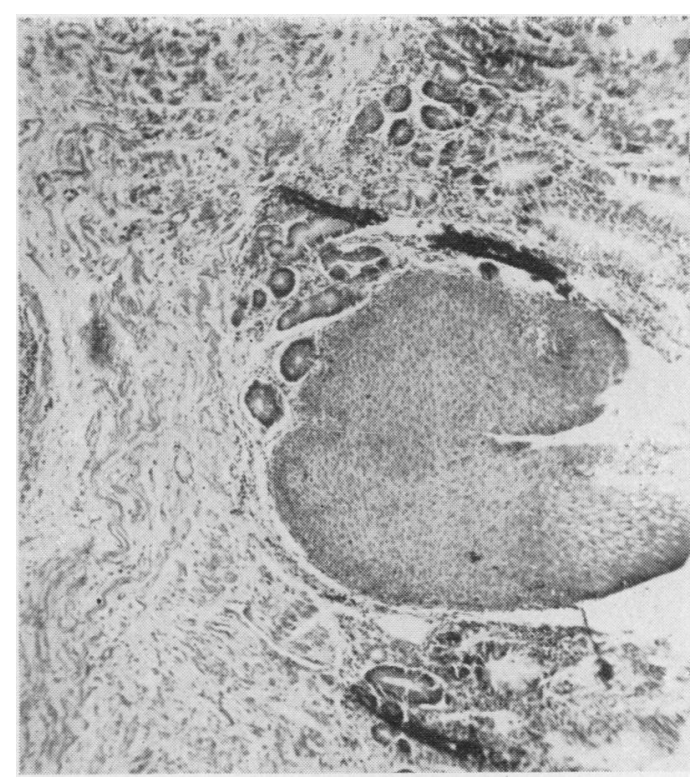

FIG. 16. Squamous islet in gastric mucosa. Haematoxylin and eosin. $\times 51$.

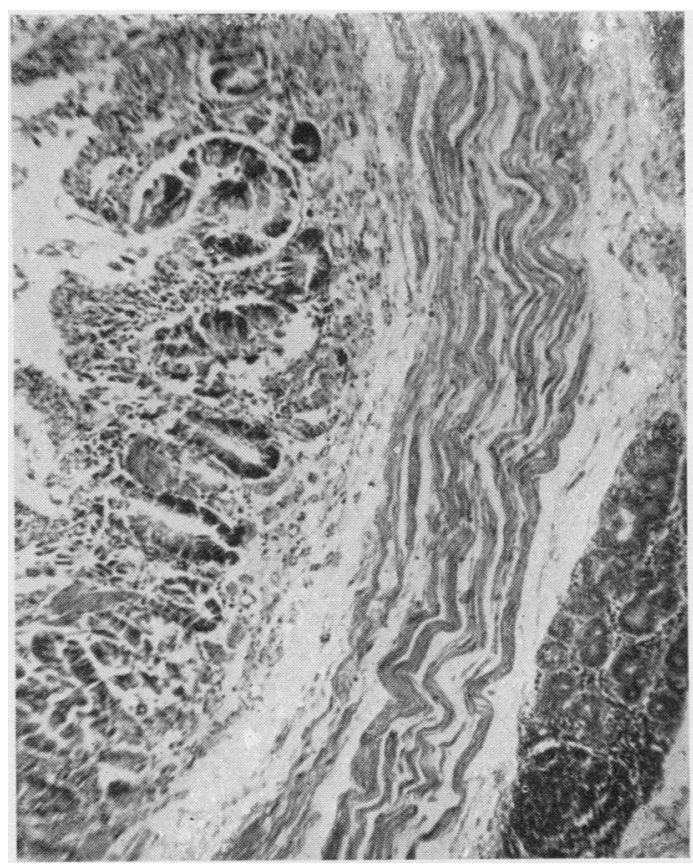

FIG. 17.-Oesophageal mucous gland in submucosa. Haematoxylin and eosin. $\times 61$.

Figs. 15, 16, and 17.-Microscopic details of Fig. 14. 


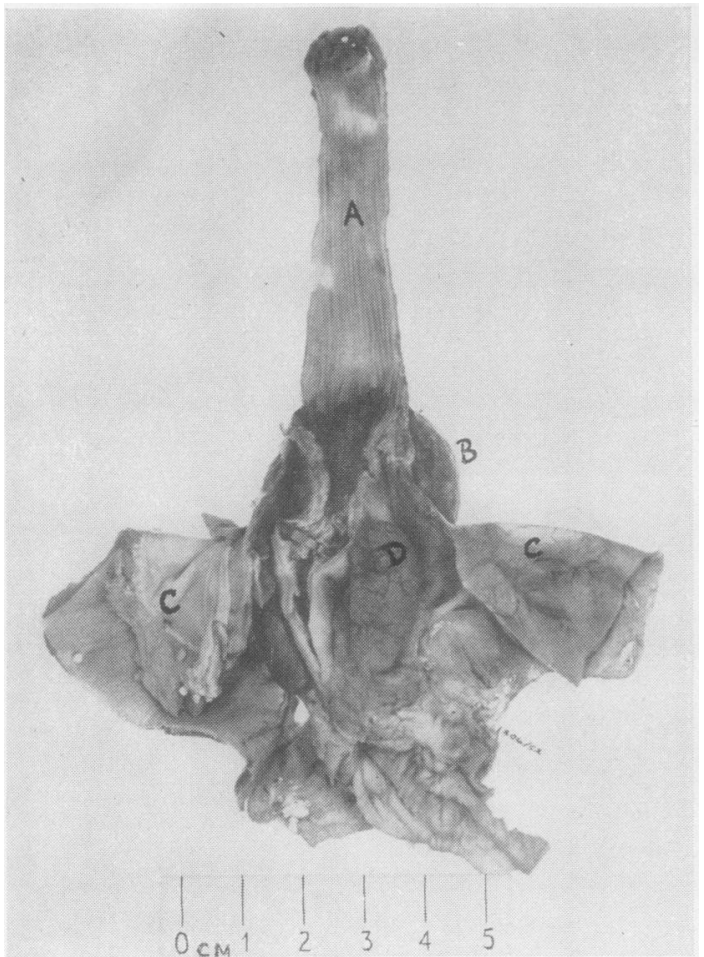

FIG. 18.-Congenital short squamous oesophagus. Gastric part in differentiated stomach form. A. Squamous oesophagus. B. Gastric fundus. C. Diaphragm. D. Pancreas.

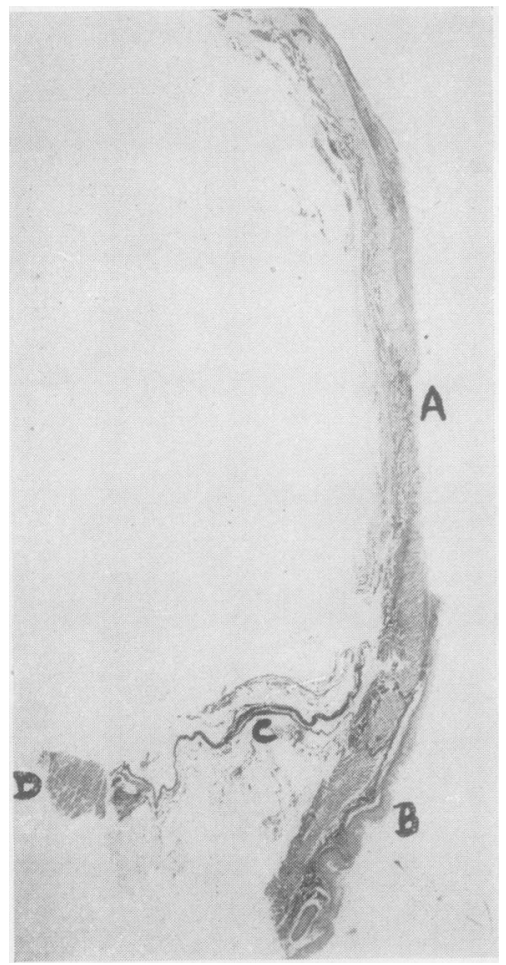

FIG. 20

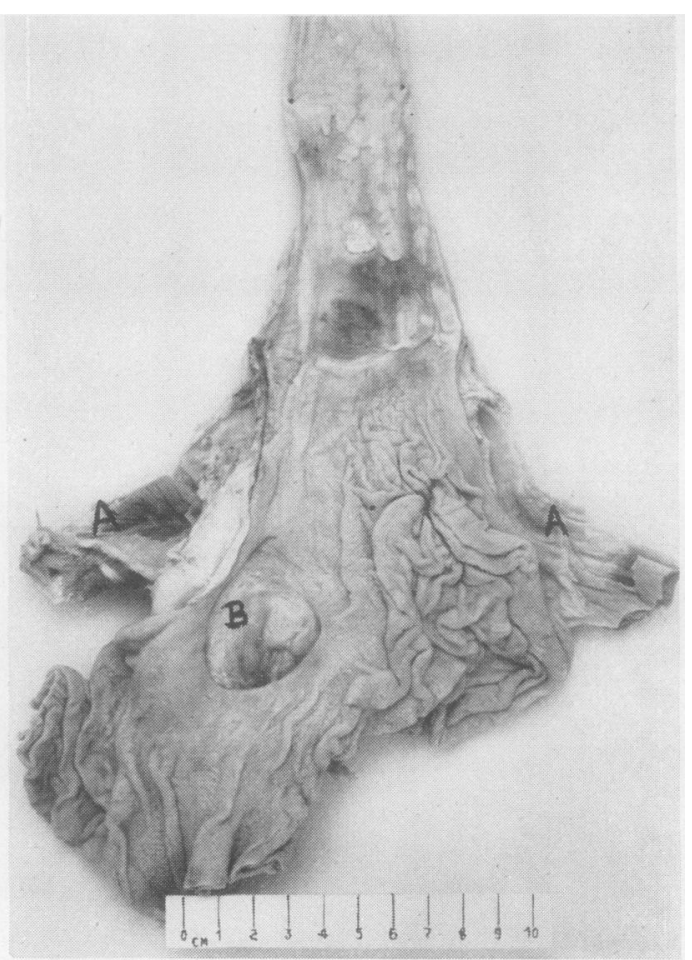

FIG. 19.-Congenital enlargement of hiatus and chronic ulcerated oesophagitis with slight shortening. A. Diaphragm. B. High lesser curve chronic gastric ulcer.

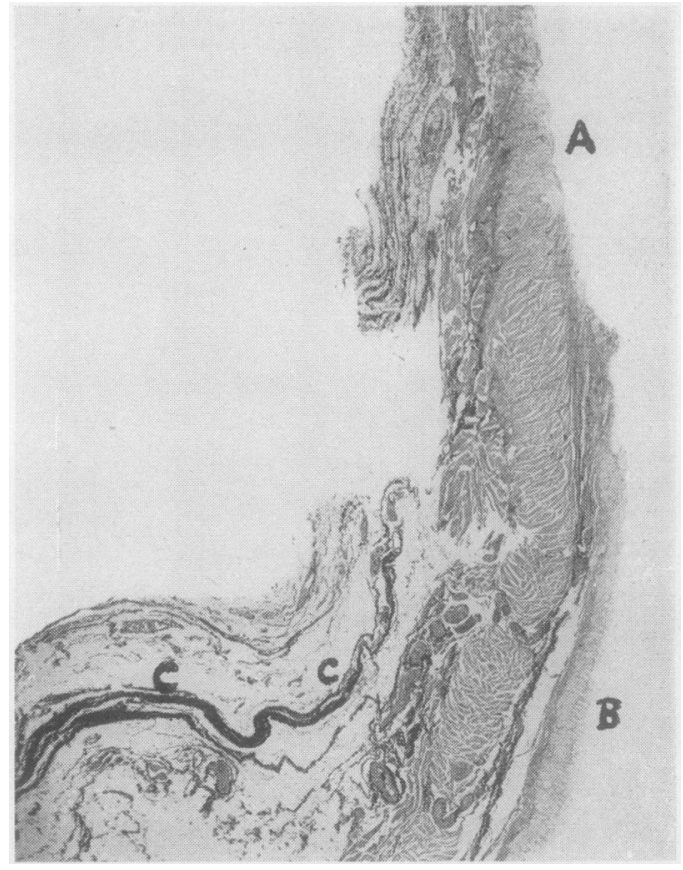

Fio. 21

FIGs. 20 and 21.-Hypertrophied elastic diaphragmatico-oesophageal ligament spanning a large hiatus. The sections were taken from the specimen illustrated in Fig. 19. Haematoxylin and van Gieson stain and elastic. Fig. $20 \times 1 \frac{1}{4}$ approximately and Fig. 21 $\times 4$ approximately. A. Ulcerated oesophagus. B. Stomach. C. Elastic ligament. D. Diaphragm. 


\section{Discussion}

Although tables should speak for themselves, a few points of interest may be abstracted. The cases are too few to have much statistical weight.

(1) Nearly all the specimens showed chronic ulcerative oesophagitis in the squamous part. In the short oesophagus series, there was ulceration in the gastric part (Barrett's ulcer) in about half.

(2) There was primary adenocarcinoma of the gastric part (Fig. 10) in $14.3 \%$ of the short oesophagus cases. From the latest available RegistrarGeneral's statistical review, approximately $2.8 \%$ of all deaths in England and Wales in 1954 were due to gastric neoplasm. Smithers (1950) has recently published a detailed analysis of 31 cases of adenocarcinoma of the oesophagus. The condition has also been discussed by Barrett (1957).

(3) In about half the cases (45.8\%) other major congenital malformations were present ; in a further $20.8 \%$ there were doubtfully significant or doubtful congenital abnormalities (total $66.6 \%$ ). A curiosity is two cases of short oesophagus having very similar skeletal abnormalities, including rudimentary digits and symmetrical hyperostoses.

(4) In six cases $(27.3 \%)$ gross mental disorder had been present in life. In one (Case 14) it could probably be accounted for by age and anaemia ; of the remaining five, three were lifelong mental defectives and two were chronic psychotics (one of them schizophrenic since puberty).

GENERAL INCIDENCE.-The present cases occurred in a series of approximately 25,000 necropsies, giving the following figures for overall incidence:

Congenital short oesophagus ... ... $0.084 \%$ Congenital enlargement of hiatus only ... $0.016 \%$

Combined total of about 1 in 1,000 necropsies

Age INCIDENCE.-The average age at death was about 62 years so that, although early death may be caused in individual cases, e.g., Case 2, on the whole the malformations and resultant lesions do not appear seriously to shorten life.

SEX INCIDENCE.-No significant preponderance of either sex was found (13 female, 12 male).

Pathogenesis and Terminology.-It is relevant at this point to reiterate the view of Lewis (1912), who pointed out that it is the differential growth in the embryo of the entodermal foregut (ultimately represented by the definitive mucosa) which governs the shape of the final viscus. In the congenital short oesophagus it seems that where the atypical gastric epithelium is of fundal type the gross viscus resembles stomach in shape, whereas if it is of cardiac type the form tends to be tubular, i.e., as a much drawn-out gastric cardia or junctional zone. Both' of these forms may show the oesophageal feature of mucous glands below the muscularis mucosae, that is to say, the wall of the anomalous organ, whatever its shape or mucosa, may retain a microscopic oesophageal characteristic. It is an atypical structure, neither oesophagus nor stomach (see also Barrett, 1957), or alternatively both. There would seem, however, no fundamental objection to the old-established term "congenital short oesophagus," especially if qualified by the word "squamous."

The evidence, such as it is, suggests that the essential abnormality is a relative failure of differentiation of the oesophageal part of the primitive entodermal foregut ; the squamous anlage appears to be inadequate, and this, associated with insufficient "caudal migration" in the early embryo, is eventually revealed as shortness of the proper epithelium in the final organ. This view corresponds in some degree with the conception of a graded failure of normal transformation or maturation of the embryonic oesophageal epithelium advanced by Smithers (1956) and Barrett (1957).

\section{SUMMARY}

The congenital malformations directly related to digestion oesophagitis are: (a) Congenital shortness of the squamous oesophagus with or without a large hiatus; $(b)$ enlargement of the hiatus alone.

The incidence, morbid anatomy, pathological diagnosis, and pathogenesis of these two conditions are discussed on the basis of 25 cases.

I wish to thank Dr. A. B. Bratton, Professor W. J. Hamilton, Dr. M. Hynes, and Dr. S. H. G. Robinson for reading the draft and for much helpful criticism. Mr. N. R. Barrett kindly permitted the inclusion of three cases previously published by him. I am indebted to Mr. G. W. Moore, Mr. H. S. Cox, and Mr. C. M. Cook for the photographs ; also to Mrs. H. M. Page for secretarial help.

This paper is based on Part III of a thesis for the degree of D.M. of Oxford (1952).

\section{REFERENCES}

Allison, P. R. (1951). Festival Oration:

and Johnstone, A. S. (1953). Thorax, 8, 87

Arey, L. B. (1934). Developmental Anatomy, 3rd ed. W. B. Saunders, Philadelphia and London.

Barrett, N. R. (1950). Brit. J. Surg., 38, 175.

(1954). Ibid., 42, 231.

(1954). Ibid., 42, 231.

Findlay, L., and Brown Kelly, A. (1931). J. Laryng., 46, 797.

Hamilton, W. J., Boyd, J. D., and Mossman, H. W. (1952) Human Embryology, 2nd ed. Heffer, Cambridge.

Harrington, S. W. (1940). Amer. J. Surg., 50, 381.

Hume, J. B. (1932). Brit. J. Surg., 19, 527.

Lewis, F. T. (1912). Amer. J. Anat.. 13, 477.

Lyall. A. (1937). Brit. J. Surg., 24, 534.

Morson, B. C. (1956). Personal communication

- and Belcher, J. R. (1952). Brit. J. Cancer, 6, 127.

Peters, P. M. (1952). Thesis, Oxford University.

(1955). Thorax, 10, 269.

Smithers, D. W. (1956). Ibid., 11, 257.

Stewart, M. J., and Hartfall, S. J. (1929). J. Path. Bact., 32, 9.

Tileston, W. (1906). Amer. J. med. Sci., 132, 240. 